Elsevier

GENE 1141

\title{
Cloning and expression in Escherichia coli K-12 of the structural gene for outer membrane PhoE protein from Enterobacter cloacae
}

(Recombinant DNA; pore protein; phosphate limitation; pho regulon; RP4:: mini-Mu; $\gamma \delta$ insertion element; vaccines)

\author{
Cornelis Verhoef, Chris van Koppen, Piet Overduin, Ben Lugtenberg*, Jaap Korteland and Jan Tommassen** \\ Institute of Molecular Biology and Department of Molecular Cell Biology, State University of Utrecht, Transitorium 3, \\ Padualaan 8, $3584 \mathrm{CH}$ Utrecht (The Netherlands) Tel. (30)532999
}

(Received June 14th, 1984)

(Revision received July $23 \mathrm{rd}$, 1984)

(Accepted August 2nd, 1984)

\section{SUMMARY}

In Escherichia coli $\mathrm{K}-12$, the $p h o E$ gene encodes an outer membrane pore protein, which is induced by phosphate starvation. The corresponding gene of Enterobacter cloacae was transferred to $E$. coli $\mathrm{K}-12$ by using RP4:: mini Mu plasmid pULB 113 and selecting for R-prime plasmids that carry the genes pro $A$ and proB, which are closely linked to $p h o E$ in $E$. coli K-12. The phoE gene was subcloned into the multicopy vector pACYC184, and the location of the gene was determined by analysis of in vitro constructed deletion plasmids and mutant plasmids generated by $\gamma \delta$ insertions. The $E$. cloacae $p h o E$ gene is normally expressed in $E$. coli $\mathrm{K}-12$, and the regulation of the expression is similar to that of the $E$. coli phoE gene. Functionally, the products of the $p h o E$ genes of $E$. coli $\mathrm{K}-12$ and $E$. cloacae behave very similarly since they form pores in the outer membrane with a recognition site for negatively charged compounds and they serve as (part of) the receptor for phage TC45.

\section{INTRODUCTION}

The outer membrane of Enterobacteriaceae functions as a barrier for harmful compounds. The

\footnotetext{
* Present address: Department of Plant Molecular Biology, State University of Leiden, Botanical Laboratory, Nonnensteeg 3, 2311 VJ Leiden (The Netherlands) Tel. (71) 148333, Ext. 6663.

** To whom correspondence and reprint requests should be addressed.
}

Abbreviations: Ap, ampicillin; $b p$, base pairs; $\mathrm{Cm}$, chloramphenicol; EtBr, ethidium bromide; $\mathrm{kb}, 1000 \mathrm{bp}$; $\mathrm{Kn}$, kanamycin; LPS, lipopolysaccharide; ${ }^{\text {R }}$ (superscript), resistant; Rf, rifampicin; SDS, sodium dodecyl sulfate; Sm, streptomycin; Tc, tetracycline;::, novel joint; [ ], indicates plasmid-carrier state. membrane contains a number of abundant proteins, designated as porins or pore proteins, which allow the influx of nutrients. These pore proteins function as nonspecific diffusion channels through which small hydrophilic solutes with $M_{\mathrm{r}} \mathrm{s}$ up to about 700 can pass (for a review, see Nikaido, 1979).

Under standard laboratory conditions, E. coli $\mathrm{K}-12$ produces two distinct pore proteins, namely OmpC and OmpF (Van Alphen et al., 1978). The synthesis of another pore protein, designated as PhoE protein, is induced when cells are grown under phosphate limitation (Overbeeke and Lugtenberg, 1980a). The primary structure of these porins, OmpF, OmpC and PhoE is very similar (Mizuno et al., 1983). However, in contrast to the $\mathrm{OmpF}$ and 
OmpC proteins, PhoE protein forms pores with a preference for negatively charged solutes (Korteland et al., 1982; Nikaido et al., 1983; Overbeeke and Lugtenberg, 1982).

The synthesis of PhoE protein is subject to a complex regulatory system in which three regulatory genes are involved, namely $p h o B, p h o R$ and phoM (Tommassen and Lugtenberg, 1980; Tommassen et al., 1982a, 1984; Wanner and Latterell, 1980). Also, mutations in the genes phoS, phoT, phoU and $p s t$, which are primarily involved in phosphate transport, affect the expression of $\mathrm{PhoE}$ protein, in that the protein is produced constitutively in strains carrying any of these mutations (Tommassen and Lugtenberg, 1980).

For two reasons we are interested in studying the expression of phoE genes from other Enterobacteriaceae in $E$. coli $\mathrm{K}-12$ : (i) cloning, sequence analysis and studies on the expression and functioning of the "foreign" phoE genes and their products are expected to contribute significant information to our studies on the regulation, biogenesis and structure-function rclationship of PhoE protein, and (ii) since outer membrane proteins are potential constituents of vaccines against pathogenic Gram-negative bacteria, their expression in $E$. coli $\mathrm{K}-12$ would be very useful for isolating large quantities of these proteins. Thus, it would be interesting to determine whether the structural genes for outer membrane proteins of other Gram-negative bacteria are expressed in E. coli $\mathrm{K}-12$. The cloning of the Enterobacter cloacae phoE gene in $E$. coli $\mathrm{K}-12$ is described in this paper. It appears to be normally expressed.

\section{MATERIALS AND METHODS}

\section{(a) Bacterial strains, phages and growth conditions}

The bacterial strains and their characteristics are listed in Table I. Spontaneous Rf-resistant mutants were obtained by plating $3 \times 10^{8}$ cells of an overnight culture on plates containing $40 \mu \mathrm{g} / \mathrm{ml} \mathrm{Rf}$. Mutants with a heptose-deficient LPS were isolated with the aid of the LPS-specific phages T3, T4 and T7 as described earlier (Havekes et al., 1976). Phage TC45 uses PhoE protein as part of its receptor (Chai and Foulds, 1978). Phage GU5 is specific for strains containing IncP plasmids (Van Gysegem and Toussaint, 1982).

Except where noted, cells were grown overnight at $37^{\circ} \mathrm{C}$ under aeration in L-broth, which contains $1 \%$ tryptone, $0.5 \%$ yeast extract, $0.5 \% \mathrm{NaCl}, 0.002 \%$ thymine, pH 7.0. Minimal medium used for the selection of auxotrophic markers (Lugtenberg et al,

\section{TABLE I}

Bacterial strains and their characteristics ${ }^{\text {a }}$

\begin{tabular}{|c|c|c|}
\hline Strain & Characteristics & Reference/Source \\
\hline \multicolumn{3}{|c|}{ E. coli K-12 } \\
\hline $\mathrm{AB} 1157$ & $\mathrm{~F}^{-}$, thr leu $A(p r o A-p r o B-p h o E-g p t)$ his thi argE lacY galK xyl rpsL & Adelberg \\
\hline CE1194 & phoS2l bgl transductant of $\mathrm{AB} 1157$ & Tommassen et al, $1982 \mathrm{~b}$ \\
\hline CE1195 & pro $^{+}$phoE $E^{+}$transductant of CE1 194 & Tommassen et al., 1982b \\
\hline CE1224 & $o m p R$ derivative of $\mathrm{AB} 1157$ & Tommassen et al., 1983 \\
\hline CE1223 & recA56 his ${ }^{+}$derivative of CE1194 & Tommassen et al., 1983 \\
\hline CE1226 & thr ${ }^{+} h s d R$ hsdM his ${ }^{+}$recA56 derivative of CE1194 & This study \\
\hline MXR & $\Delta($ lac-pro $)$ galE thi recAl & Van Gysegem and Toussaint, 1982 \\
\hline CE1227 & $\begin{array}{l}\mathrm{F}^{-}, \text {thr leu thi pyrF thy ilvA } \operatorname{lac} Y \text { arg } G \text { tonA tsx rpsL cod deoC vtr glpR } \\
\text { pho } \$ 200 \text { phoB201 recA56 }\end{array}$ & This study \\
\hline CE1225 & thi rpsL phoR68 phoM453 lac recA56 & Tommassen et al., 1984 \\
\hline CE1238 & $\begin{array}{l}\mathrm{F}^{-} \text {, thi pyrF thy ilvA his argG tonA rpsL deoC vtr glpR ompR } 471 \text { phoR69 } \\
\text { phoA8 } \Delta(p r o A, B-p h o E)\end{array}$ & Korteland et al., 1982 \\
\hline CE1304 & $F^{\prime}$ lac ${ }^{+}$, thr thi recA171 lac Z22 lacI rpsL rpoB supE & De Geus et al., 1983 \\
\hline \multicolumn{3}{|c|}{ Enterobacter cloacae } \\
\hline $\mathrm{H} 478$ & his & De Graaf \\
\hline
\end{tabular}

\footnotetext{
${ }^{a}$ Nomenclature according to Bachmann (1983).
} 
1976) and low- and high-phosphate containing minimal media (Tommassen and Lugtenberg, 1980) have been described previously. To select for antibiotic resistance, the following concentrations were used: Ap $50 \mu \mathrm{g} / \mathrm{ml}, \quad C m 25 \mu \mathrm{g} / \mathrm{ml}, \quad \mathrm{Kn} 50 \mu \mathrm{g} / \mathrm{ml}, \quad \mathrm{Sm}$ $100 \mu \mathrm{g} / \mathrm{ml}$ and Tc $10 \mu \mathrm{g} / \mathrm{ml}$. For plating, mcdia werc solidified with Difco agar at a final concentration of $1.5 \%$.

\section{(b) Genetic techniques}

Matings between donor strains carrying RP4derived plasmids and recipient strains were performed as described by Van Gysegem and Toussaint (1982). Transformation was carried out as described by Brown et al. (1979). Sensitivity to phages was determined by cross-streaking.

\section{(c) Cell envelope preparation}

Cell envelopes were isolated by differential centrifugation after ultrasonic disruption of cells (Lugtenberg et al., 1975). Protein patterns of cell envelopes were analyzed by SDS-polyacrylamide gel electrophoresis as described by Lugtenberg et al. (1975), except that $4 \mathrm{M}$ urea was added to the running gel where indicated.

\section{(d) DNA preparation}

Crude plasmid DNA was prepared as described by Birnboim and Doly (1979). DNA, needed for in vitro recombination experiments, was further purified by $\mathrm{CsCl}-\mathrm{EtBr}$ isopycnic centrifugation. Ligation with T4 DNA ligase was performed as described by Tanaka and Weisblum (1975). Analyses of plasmid DNA and DNA fragments were performed by electrophoresis in a horizontal $0.6 \%$ agarose slab gel (Van den Hondel et al., 1979).

(e) Isolation of plasmids carrying an inserted $\gamma \delta$ transposable element

Insertions of the transposable element $\gamma \delta$ in plasmid pEC17 were obtained as described by Guyer (1978). Plasmid pEC17 was transformed into the $\mathrm{F}^{\prime}$ lac $^{+}$-containing strain CE1304, selecting for $\mathrm{Cm}^{\mathrm{r}}$ colonies. One transformant was used as a donor in a mating with strain CE1238 as the recipient, selecting for $\mathrm{Cm}^{\mathrm{R}}$, leu ${ }^{+}$-colonies. Transconjugants with a $\gamma \delta$ insertion on $\mathrm{pEC} 17$ inside or outside of phoE were identified as resistant or sensitive to phage TC45, respectively.

\section{(f) Rate of permeation of $\beta$-lactam antibiotics}

The rate of permeation of $\beta$-lactam antibiotics through the outer membrane and the inhibition of this permeation by polyphosphate were measured using a method originally described by Zimmerman and Rosselet (1977) and modified by Overbeeke and Lugtenberg (1982), except that the final concentrations of the antibiotics cefsulodin and cephaloridine in the suspensions were $0.8 \mathrm{mM}$ instead of 0.7 and $0.9 \mathrm{mM}$, respectively.

\section{RESULTS}

(a) Transfer of the proA-proB region of the E. cloacae genome to $E$. coli K-12

For cloning of the phoE gene of E. cloacae the RP4:: mini Mu plasmid pULB113 was used. This plasmid is a derivative of the wide host-range conjugative plasmid RP4 and carries a deleted Mu prophage which allows the plasmid to pick up any chromosomal DNA segment to form R-prime plasmids (Van Gysegem and Toussaint, 1982). The plasmid renders cells resistant to the antibiotics Ap, $\mathrm{Kn}$ and Tc. Whereas there is no direct selection for expression of a cloned $p h o E$ gene available, we could take advantage of the observation that $p h o E$ in $E$. coli $\mathrm{K}-12$ is located very close to the selectable markers pro $A$ and pro $B$ (Tommassen and Lugtenberg, 1981; Tommassen et al., 1982b).

Plasmid pULB113 was transferred to an $\mathrm{Rf}^{\mathrm{R}}$ derivative of $E$. cloacae strain $\mathrm{H} 478$ by conjugation with donor strain MXR [pULB113], selecting for $\mathrm{Kn}^{\mathrm{R}}$ and $\mathrm{Rf}^{\mathrm{R}}$ transconjugants. One transconjugant was subsequently used as a donor strain in a mating with phoS recA strain $\mathrm{CE} 1226$ as the recipient. The latter host contains a proA-proB-phoE-gpt deletion. All ten $\mathrm{Sm}^{\mathrm{R}}$ pro $^{+}$transconjugants tested contained a RP4::mini Mu plasmid, since they were $\mathrm{Ap}^{\mathrm{R}}$, $\mathrm{Kn}^{\mathrm{R}}$, sensitive to the Inc-P plasmid-specific phage GU5, and immune to $\mathrm{Mu}$. Plasmid preparations 
from these transconjugants all exhibited a band which migrated more slowly on agarose gels than the original pULB 113 (results not shown), suggesting that $\mathbf{R}^{\prime}$ plasmids were obtained. One of these plasmids, designated as pEC10, was further analyzed.

\section{(b) Presence of $E$. cloacae phoE gene on pEC10 and its expression in $E$. coli $\mathrm{K}-12$}

Evidence for the presence of an E. cloacae phoE gene on $\mathrm{pEC10}$ is obtained if a protein, similar to the E. coli PhoE protein, is expressed in a pEC10containing derivative of phoS phoE strain CE1226. In contrast to the parental strain CE1226, the pEC10-containing transconjugant turned out to be sensitive to the PhoE protein-specific phage TC45, showing that a PhoE-like protein is expressed in the latter strain.

Analysis of the cell envelope protein patterns of these strains on SDS-polyacrylamide gels did not reveal a band in the position of the $E$. coll $\mathrm{PhoE}$ protein in any of these strains (Fig. 1A, lanes $c$ and d). However, the band in the position of OmpF protein, which migrates slightly faster in the gel than PhoE protein, was heavier stained in case of the cell envelopes of the pEC10-containing strain, suggesting that this band might contain the E. cloacae PhoE protein as well as the OmpF protein. Therefore, the cell envelopes were also analyzed in a running gel,

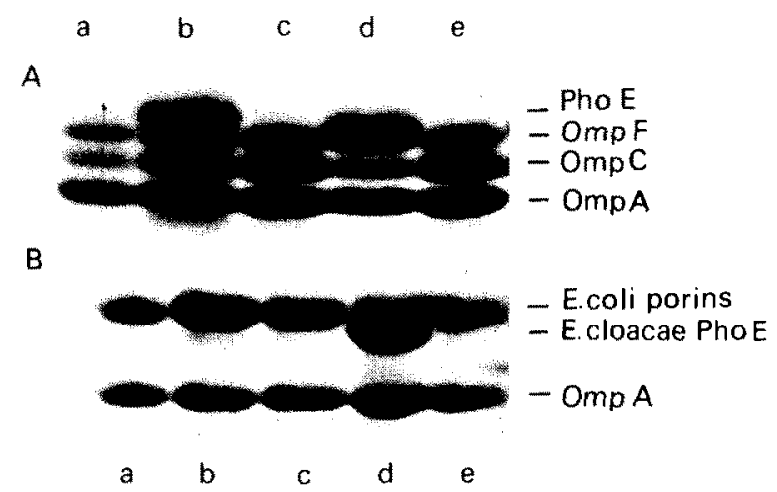

Fig. 1. Cell envelope protein patterns as analyzed by SDSpolyacrylamide gels, either according to Lugtenberg et al. (1975) (panel A), or on gels supplemented with $4 \mathrm{M}$ urea (panel B). The lanes contain cell envelope preparations of phoS phoE strain CE1194 (a), phoS phoE ${ }^{+}$strain CE1195 (b), phoS phoE strain CE1226 (c), CE1226 [pEC10] (d), and of a TC45-resistant derivative of the latter strain (e). Only the relevant part of the gels, containing the proteins with apparent $M_{\mathrm{r}}$ s between 35000 and 40000 , is shown. which was supplemented with $4 \mathrm{M}$ urea, since this is known to result in another resolution of the proteins (Overbeeke and Lugtenberg, 1980b). As shown in Fig. 1B, an additional band was now found in the cell envelopes of the pEC10-containing strain (lane d), which migrates slightly faster in the gel than E. coli PhoE protein and which was not observed in the cell envelopes of a plasmidless strain (lane $c$ ) or in the cell envelopes of a TC45-resistant derivative, isolated from CE1226-containing pEC10 (lane e). Therefore, this band represents the $E$. cloacae $\mathrm{PhoE}$ protein.

\section{(c) Subcloning of the E. cloacae phoE gene}

For a physical analysis of the E. cloacae phoE gene, this gene was subcloned from pEC10 into the multicopy vector $\mathrm{pACYC184}$. The latter plasmid renders cells resistant to $\mathrm{Cm}$ and $\mathrm{Tc}$ and contains unique sites for $S a I I$ and BamHI in the $\mathrm{Tc}^{\mathrm{R}}$ gene (Chang and Cohen, 1978). For cloning of the phoE gene, pACYC184 was digested with both enzymes to prevent re-circularization of the vector DNA during subsequent ligation. Purified $\mathrm{pEC10}$ was also digested with SalI and BamHI and, after inactivation of the restriction enzymes, the DNA preparations were mixed, ligated with T4 DNA ligase and transformed into strain $\mathrm{CE} 1226$, selecting for $\mathrm{Cm}^{\mathrm{R}}$ colonies. Plasmid DNA was isolated from one transformant that was sensitive to $\mathrm{TC} 45$, showing that the $E$. cloacae phoE gene had been cloned. This $19.7-\mathrm{kb}$ plasmid, designated as pEC11, contains one Sall site, two BamHI sites and five $P_{s t I}$ sites (not shown). PstI does not cleave the vector DNA. For further subcloning of phoE, $\mathrm{pEC} 11$ was partially digested with PstI. After inactivation of the enzyme and ligation with T4 DNA ligase, the DNA preparation was transformed into strain CE1226. Plasmid DNA was isolated from one $\mathrm{Cm}^{\mathrm{R}}$, TC45-sensitive transformant. The plasmid, pEC12, is $10.7 \mathrm{~kb}$ long (not shown). To adapt the plasmid DNA to the restriction-modification system of E. coli $\mathrm{K}-12$, the DNA was passed through $h s d R^{+} h s d M^{+}$strain CE1223. Plasmid DNA from one $\mathrm{Cm}^{\mathrm{R}}$, TC45-sensitive transformant was further studied and is designated as pEC13.

To prepare a restriction map of pEC13 (Fig. 2), fragments of pEC13 generated by single and double digestions with several restriction enzymes, were 


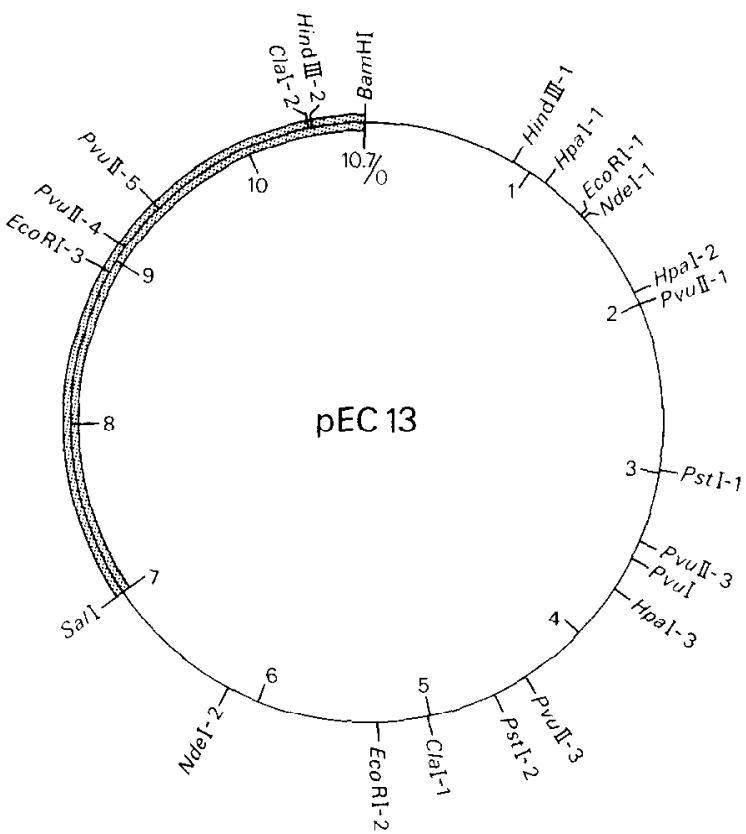

Fig. 2. Restriction map of plasmid pEC13. The pACYC184 vector is indicated by the shaded scgment. Map units are in $\mathbf{k b}$. The plasmid contains no BglII, MluI and SmaI sites. analyzed on agarose gels. The position of the pACYC184 vector was deduced from its known restriction map (Chang and Cohen, 1978).

\section{(d) Physical localization of the E. cloacae phoE gene on pEC13}

To localize the phoE gene, deletion mutant plasmids of $\mathrm{pEC} 13$ were constructed in vitro by digesting purified pEC13 DNA with HindIII, ClaI, NdeI, HpaI or PstI. After subsequent ligation, the DNA preparations were transformed into strain CE1223, selecting $\mathrm{Cm}^{\mathrm{R}}$ colonies. Plasmid DNA was isolated from the transformants and plasmids pEC14, 15, 16, 17 and 18 were selected for further characterization. The presence of a functional phoE gene on the plasmids was determined by testing the transformants for sensitivity to TC45. The results of the analysis of the deletion plasmids are shown in Fig. 3. Since pEC17, in contrast to $\mathrm{pEC18}$, contains a functional $p h o E$ gene, this gene must be (partially) located on the

pEC13

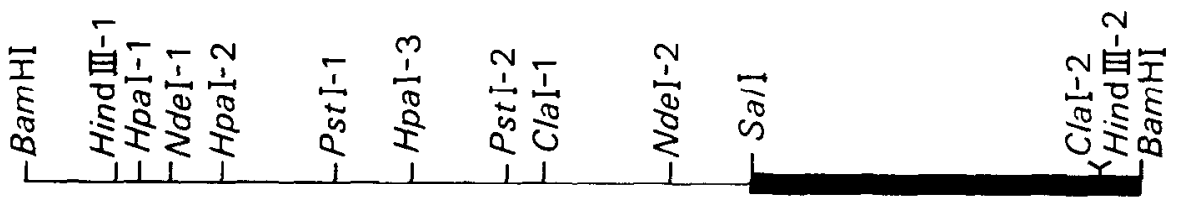

PhoE $^{+}$

pEC14

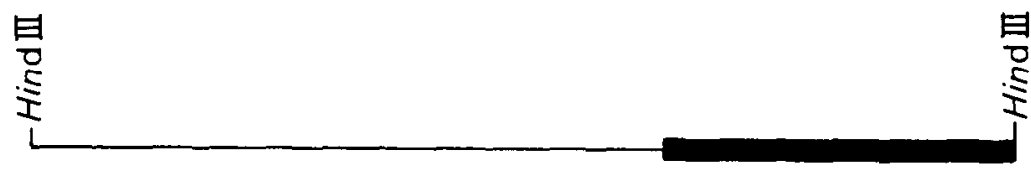

$\mathrm{PhoE}^{+}$

pEC 15

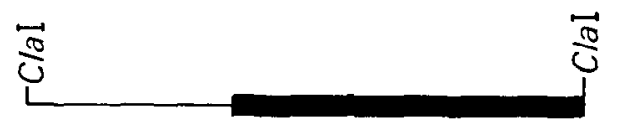

PhoE ${ }^{-}$
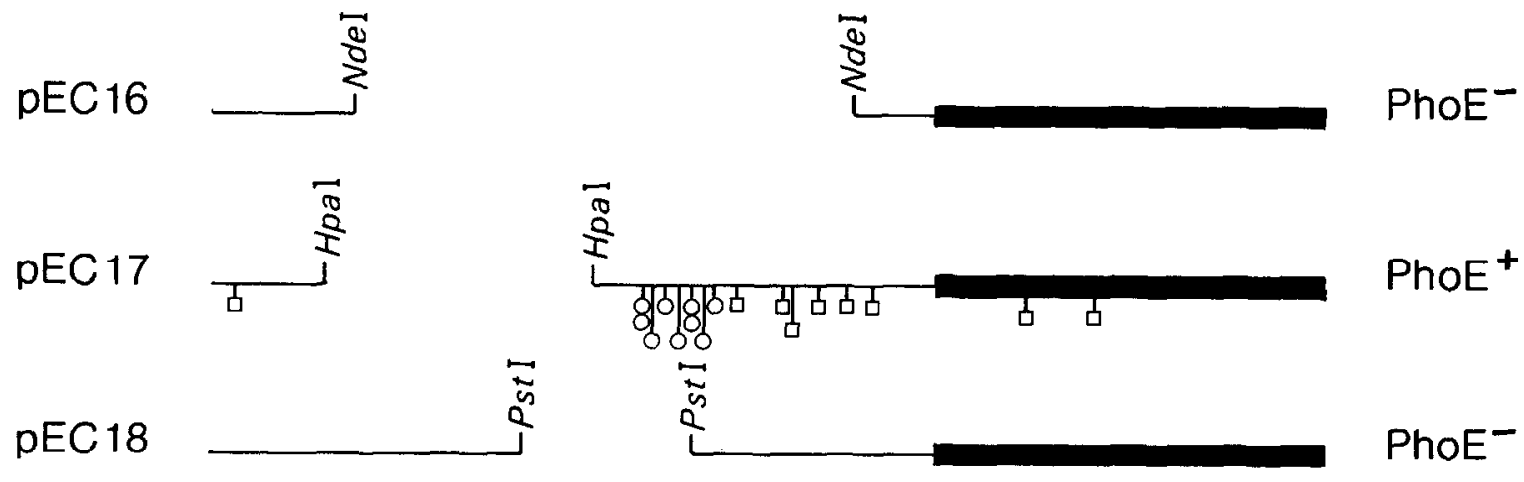

\section{pEC18}
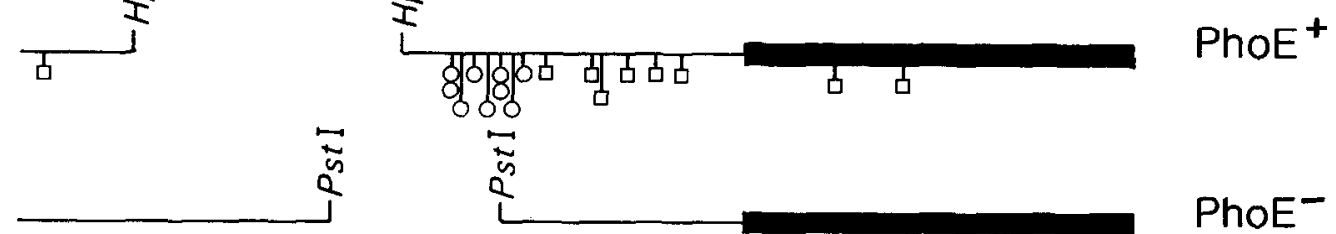

Fig. 3. Localization of $E$. cloacae phoE gene on $\mathrm{pEC} 13$ and on derivative plasmids. The presence of a functional phoE gene on the plasmids was determined by testing plasmid-containing strains for sensitivity to TC45. The locations of the $\gamma \delta$ insertions in pEC17 are also indicated: insertions that inactivate the $p h o E$ gene are indicated by circles (o) and insertions outside phoE by squares ( $\square$ ). Shaded segments represent pACYC184 vector (see Fig. 2). 
0.9-kb DNA fragment between the HpaI-3 and PstI-2 sites of pEC13, whereas the rest of the gene must be located on the PstI-2 to Sall fragment.

This result was confirmed by the analysis of mutant plasmids of $\mathrm{pEC17}$, generated with the aid of the transposable elcment $\gamma \delta$ of the F plasmid. The $\gamma \delta$ insertions in pEC17 were obtained as described in MATERIALS AND METHODS, section e, and the locations of the insertions were mapped using ClaI-, SalI-, and BamHI-generated restriction fragments. $\mathrm{ClaI}$ and $\mathrm{Sal \textrm {I }}$ cleave the $5.6-\mathrm{kb} \gamma \delta$ element approximately in the middle, whereas BamHI cleaves at $0.2 \mathrm{~kb}$ from one end. The results (Fig. 3) show that the insertions in phoE are clustered in a region of approx. $0.7 \mathrm{~kb}$, which corresponds with the region predicted from the analysis of the deletion mutant plasmids.

(e) Regulation of the expression of the $E$. cloacae phoE gene in $E$. coli K-12

To determine whether the expression of the $E$. cloacae phoE gene in $E$. coli $\mathrm{K}-12$ is subject to the same regulatory system as the expression of the E. coli phoE gene, pEC13 was transformed into strain CE1224, which is wild type for all pho regulatory genes, phoS strain CE1194, phoS phoB strain CE1227, phoR strain CE1238 and phoR phoM strain CE1225. Cell envelope protein patterns of the transformants were analyzed on SDS-polyacrylamide gels containing $4 \mathrm{M}$ urea (Fig. 4). The E. cloacae $\mathrm{PhoE}$ protein is produced in CE1224 only when cells are grown under phosphate limitation (lanes $a$ and $b$ ). The protein is produced constitutively in phoS strain CE1194 (lane c) but the syn- thesis of the protein is dependent on the phoB product (lane d). The protein is also produced constitutively in phoR strain CE1238 (lane e), and the constitutive synthesis in a phoR strain is dependent on the phoM product (lane f). In all these respects, the expression of the E. cloacae $\mathrm{PhoE}$ protein is exactly the same as that of the $E$. coli $\mathrm{K}-12$ PhoE protein (Tommassen and Lugtenberg, 1980; Tommassen et al., 1984).

The expression of E. coli PhoE protein is dependent on a wild-type $E$. coli K-12 LPS, in that mutants with a heptose-deficient LPS produce the protein in severely decreased amounts (Tommassen and Lugtenberg, 1981). Probably, during the synthesis of PhoE protein an interaction with the LPS is required at some post-translational event (Tommassen, J., Overduin, P. and Lugtenberg, B., in preparation). Also in this respect, expression of E. cloacae PhoE protein in $E$. coli $\mathrm{K}-12$ is similar to that of $E$. coli PhoE protein, since the cell envelope protein pattern of a heptose-deficient mutant of CE1238 containing pEC13 contains decreased amounts of PhoE protein (Fig. 4, compare lanes e and g).

\section{(f) Pore properties of the E. cloacae PhoE protein}

It has been reported that $\mathrm{PhoE}$ protein pores of $E$. coli $\mathrm{K}-12$ have a preference for anionic solutes, in contrast to OmpF and OmpC protein pores (Korteland et al., 1982; Nikaido et al., 1983; Overbeeke and Lugtenberg, 1982). This preference for negatively charged solutes has been explained in terms of a recognition site on the pore for negatively charged compounds (Overbeeke and Lugtenberg, 1982). Proof for this assumption was obtained in experi-

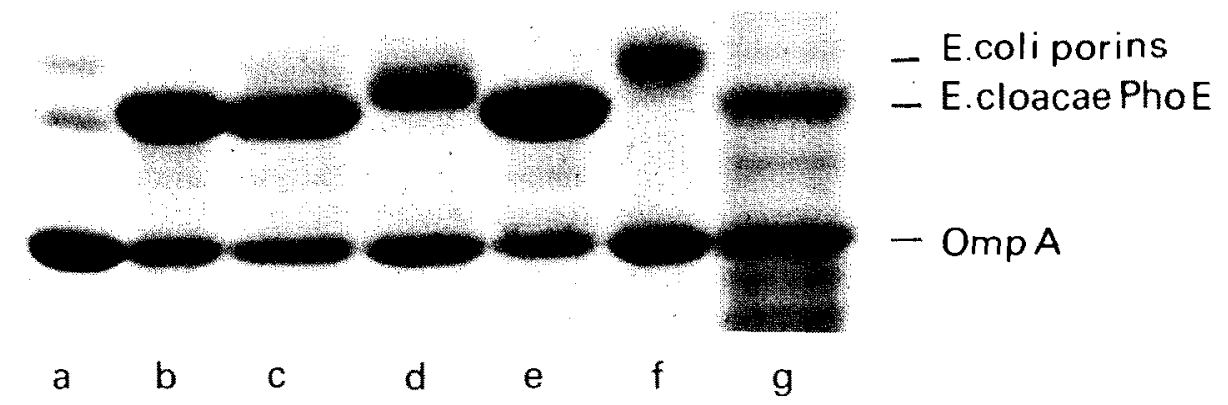

Fig. 4. Expression of the E. cloacae phoE gene in $E$. coli $\mathrm{K}-12$ strains. Cell envelope protein patterns of pEC13-containing derivatives of: phoE strain CE1224, grown in high (a) and low (b) phosphate minimal medium;phoSphoE strain CE1 194 (c); phoSphoB strain CE1227 (d); phoR phoE strain CE1238 (e); phoR phoM strain CE1225 (f) and a mutant strain of CE1238 with heptose-deficient LPS (g) are shown on an SDS-polyacrylamide gel containing $4 \mathrm{M}$ urea. 
ments showing competition for this site. Thus, permeation of $\beta$-lactam antibiotics through PhoE protein pores, but not through $\mathrm{OmpF}$ protein pores, is inhibited by negatively charged compounds, e.g., polyphosphates (Overbeeke and Lugtenberg, 1982). To determine whether this recognition site is also present on the E. cloacae PhoE protein pores, the influence of polyphosphate on the rate of permeation of the $\beta$-lactam antibiotics cephaloridine and cefsulodin was measured (Table II). The results show that the permeation of the antibiotics through the $E$. cloacae $\mathrm{PhoE}$ protein pores is inhibited even slightly more strongly than that through the $E$. coli$\mathrm{K}-12 \mathrm{PhoE}$ protein pores.

\section{DISCUSSION}

Growth of $E$. coli K-12 under phosphate limitation leads to the induction of pore protein PhoE, which is particularly efficient in the uptake of organic and inorganic phosphate (Overbeeke and Lugtenberg, 1980; Korteland et al., 1982). Its structural gene is located at min 6 on the chromosome, close to the genes pro $A$ and pro $B$ (Tommassen and Lugtenberg, 1981). We were able to demonstrate the presence of a similar gene in E. cloacae by transferring the corresponding region of the $E$. cloacae chromosome to $E$. coli $\mathrm{K}-12$.

Previous studies on the intergeneric exchange of major outer membrane protein genes gave varying results with respect to the expression of these genes.
Whereas the cloned ompA genes of Shigella dysenteriae, Enterobacter aerogenes and Serratia marcescens are normally expressed in $E$. coli K-12 (Cole et al., 1982), it has also been reported that the ompA genes of two clinical $E$. coli isolates are only very poorly cxpressed when moved to $E$. coli K-12 by transduction (Beher et al., 1980a). Similarly, the $o m p F$ gene of $E$. coli $\mathrm{K}-12$ is very poorly expressed in $E$. coli B (Pugsley and Rosenbusch, 1983). The poor expression of these genes was supposed to be either due to a defect in transport of the proteins to the outer membrane, for which an interaction with LPS molecules is presumed to be required (Beher et al., 1980a), or due to the presence of a heterologous regulatory gene (Pugsley and Rosenbusch, 1983). We showed that the $E$. cloacae phoE gene is normally expressed in $E$. coli $\mathrm{K}-12$ and the regulation of the expression is similar to that of the E. coli $\mathrm{K}-12$ phoE gene. Thus, apparently those features of PhoE protein that are recognized by the protein export system are highly conserved, whereas the operator region of the $p h o E$ gene is also conserved.

Nucleotide sequence analysis of the cloned ompA genes from various Enterobacteriaceae (Beck and Bremer, 1980; Braun and Cole, 1983; Movva et al., 1980) suggested that OmpA protein is composed of "variable" and "constant" regions, with the variable regions probably all exposed on the cell surface. Similarly, comparison of the sequences of the $E$. coli $\mathrm{K}-12$ pore protein genes, $p h o E$, ompF and $o m p C$ reveals "variable" and "constant" regions (Mizuno et al., 1983). However, comparison of the PhoE proteins of $E$. coli $\mathrm{K}-12$ and $E$. cloacae shows that those

\section{TABLE II}

Influence of polyphosphate on the rate of permeation of $\beta$-lactam antibiotics through PhoE protein pores in the outer membrane

\begin{tabular}{|c|c|c|c|}
\hline \multirow{2}{*}{$\begin{array}{l}\beta \text {-Lactam } \\
\text { antibiotic } \\
(0.8 \mathrm{mM})\end{array}$} & \multirow[t]{2}{*}{ Polyphosphate $^{\mathbf{b}}$} & \multicolumn{2}{|c|}{ Rate of uptake by intact cells ${ }^{4}$} \\
\hline & & $\begin{array}{l}\text { CE1238 [pJP12, pBR322] } \\
\text { (E. coli } \mathrm{PhoE})\end{array}$ & $\begin{array}{l}\text { CE1238 [pEC10] } \\
\text { (E. cloacae PhoE })\end{array}$ \\
\hline \multirow[t]{2}{*}{ Cefsulodin } & - & 11.2 & 7.3 \\
\hline & + & $3.4(69 \%)$ & $1.2(82 \%)$ \\
\hline \multirow[t]{2}{*}{ Cephaloridine } & - & 9.3 & 12.8 \\
\hline & + & $2.8(70 \%)$ & $1.9(85 \%)$ \\
\hline
\end{tabular}

\footnotetext{
${ }^{a}$ Rate of uptake in the presence or absence of polyphosphate is expressed as nmol $/ \mathrm{min} / \mu \mathrm{g}$ pore protein. In parentheses: percentages of inhibition.

${ }^{b}$ The presence or absence of $0.2 \mathrm{mM}$ linear polyphosphate with average chain length of 15 phosphate residues during the uptake experiments is indicated by + or - , respectively.
} 
functions, which are related to the cell surface exposed part of the protein, i.e., a recognition site for negatively charged compounds and the phage TC45 receptor function, are conserved. In addition, it has been shown (Van der Ley, P., Amesz, H., Tommassen, J. and Lugtenberg, B., submitted for publication) that five out of six monoclonal antibodies directed against the cell surface-exposed part of PhoE protein also recognize E. cloacae PhoE protein. These results suggest that, in addition to the transmembrane stretches, the cell surface-exposed parts of PhoE protein are also highly conserved in E. coli $\mathrm{K}-12$ and E. cloacae. However, a strong homology between these phoE genes is not apparent from the restriction maps of the genes. Whereas the E. coli K-12 phoE gene contains unique PstI, MluI, ClaI, NdeI and BglII sites (Tommassen et al., 1982b; Overbeeke et al., 1983), in the E. cloacae phoE gene only the PstI site (PstI-2 in Fig. 2) is found in a position which might correspond to the PstI site in the $E$. coli phoE gene. The $P$ vuII site in the $E$. cloacae phoE gene (Fig. 3) is not found in the E. coli phoE gene.

Whereas the E. cloacae PhoE protein is able to act as the receptor for $\mathrm{TC} 45$ when produced in $E$. coli $\mathrm{K}-12$, the phage is not irreversibly absorbed by $E$. cloacae cells, induced for PhoE protein by growth under phosphate limitation (unpublished observation). Similarly, it has been reported that OmpA protein of Salmonella typhimurium functions as the receptor for phage $\mathrm{Ox} 2$ when produced by E. coli K-12 but not when produced by S. typhimurium (Freudl and Cole, 1983). However, rough mutant strains of $S$. typhimurium are sensitive to $\mathrm{O} 2$ (Beher et al., 1980b), suggesting that the O-antigen part of the LPS masks the receptor for the phage. Analogously, a permeability barrier created by the $\mathrm{O}$-antigen or a capsule might prevent the adsorption of TC45 to PhoE protein producing $E$. cloacae cells.

It is obvious that nucleotide sequence analysis of the $E$. cloacae phoE gene and comparison to the known sequence of the $E$. coli phoE gene (Overbeeke et al., 1983) will contribute to our understanding of the structure-function relationship of $\mathrm{PhoE}$ proteins. In addition, the sequence might be very useful for the analysis of the operator sequence of the $p h o E$ gene, which is subject to the complex pho regulatory system. Therefore, we are in the process of sequencing this gene.

\section{ACKNOWLEDGEMENT}

We thank M. Mergeay for supplying a pULB 113containing strain.

\section{REFERENCES}

Bachmann, B.J.: I inkage map of Escherichia coli K-12, edition 7. Microbiol. Rev. 47 (1983) 180-230.

Beck, E. and Bremer, E.: Nucleotide sequence of the gene ompA coding the outer membrane protein $\mathrm{II}^{*}$ of Escherichia coli K-12. Nucl. Acids Res. 8 (1980) 3011-3027.

Beher, M.G., Pugsley, A.P. and Schnaitman, C.A.: Correlation between the expression of an Escherichia coli cell surface protein and the ability of the protein to bind to lipopolysaccharide. J. Bacteriol. 143 (1980a) 403 410.

Beher, M.G., Schnaitman, C.A. and Pugsley, A.P.: Major heatmodifiable outer membrane protein in Gram-negative bacteria: comparison with the OmpA protein of Escherichia coli. J. Bacteriol. 143 (1980b) 906-913.

Birnboim, H.C. and Doly, J.: A rapid alkaline extraction procedure for screening recombinant plasmid DNA. Nucl. Acids Res. 7 (1979) 1513-1523.

Braun, G. and Cole, S.T.: Molecular characterization of the gene coding for major outer membrane protein OmpA from Enterobacter aerogenes. Eur. J. Biochem. 137 (1983) 495-500.

Brown, M.G.M., Weston, A., Saunders, J.R. and Humphreys, G.O.: Transformation of Escherichia coli $\mathrm{C} 600$ by plasmid DNA at different phases of growth. FEMS Microbiol. Lett. 5 (1979) 219-222.

Chai, T. and Foulds, J.: Two bacteriophages which utilize a new Escherichia coli major outer membrane protein as part of their receptor. J. Bacteriol. 135 (1978) 164-170.

Chang, A.C.Y. and Cohen, S.N.: Construction and characterization of amplifiable multicopy DNA cloning vehicles derived from the P15A cryptic miniplasmid. J. Bacteriol. 134 (1978) 1141-1156.

Cole, S.T., Sonntag, I. and Henning, U.: Cloning and expression in Escherichia coli K-12 of the genes for major outer membrane protein OmpA from Shigella dysenteriae, Enterobacter aerogenes and Serratia marcescens. J. Bacteriol. 149 (1982) 145-150.

De Geus, P., Van Die, I., Bergmans, H., Tommassen, J. and De Haas, G.: Molecular cloning of pldA, the structural gene for outer membrane phospholipase of $E$. coli K-12. Mol. Gen. Genet. 190 (1983) 150-155.

Freudl, R. and Cole, S.T.: Cloning and molecular characterization of the ompA gene from Salmonella typhimurium. Eur. J. Biochem. 134 (1983) 497-502.

Guyer, M.S.: The $\gamma \delta$ sequence of $F$ is an insertion sequence. J. Mol. Biol. 126 (1978) 347-365.

Havekes, L.M., Lugtenberg, B.J.J. and Hoekstra, W.P.M.: Conjugation deficient $E$. coli $\mathrm{K}-12 \mathrm{~F}^{-}$mutants with heptose-less lipopolysaccharide. Mol. Gen. Genet. 146 (1976) 43-50. 
Korteland, J., Tommassen, J. and Lugtenberg, B.: PhoE protein pore of the outer membrane of Escherichia coli $\mathrm{K}-12$ is a particularly efficient channel for organic and inorganic phosphate. Biochim. Biophys. Acta 690 (1982) 282-289.

Lugtenberg, B., Meyers, J., Peters, R., Van der Hoek, P. and Van Alphen, L.: Electrophoretic resolution of the "major outer membrane protein" of Escherichia coli K-12 into four bands. FEBS Lett. 58 (1975) 254-258.

Lugtenberg, B., Peters, R., Bernheimer, H. and Berendsen, W.: Influence of cultural conditions and mutations on the composition of the outer membrane proteins of Escherichia coli. Mol. Gen. Genet. 147 (1976) 251--262.

Mizuno, T., Chou, M.-Y. and Inouye, M.: A comparative study on the genes for three porins of the Escherichia coli outer membrane. DNA sequence of the osmoregulated ompC gene. J. Biol. Chem. 258 (1983) 6932-6940.

Movva, R.N., Nakamura, K. and Inouye, M.: Gene structure of the OmpA protein, a major surface protein of Escherichia coli required for cell-cell interaction. J. Mol. Biol. 142 (1980) 317-328.

Nikaido, H.: Nonspecific transport through the outer membrane, in Inouye, M. (Ed.), Bacterial Outer Membranes. Biogenesis and Functions, Wiley-Interscience, New York, 1979, pp. 361-407.

Nikaido, H., Rosenberg, E.Y. and Foulds, J.: Porin channels in Escherichia coli: studies with $\beta$-lactams in intact cells. J. Bacteriol. 153 (1983) 232-242.

Overbeeke, N. and Lugtenberg, B.: Expression of outer membrane protein e of Escherichia coli K-12 by phosphate limitation. FEBS Lett. 112 (1980a) 229-232.

Overbeeke, N. and Lugtenberg, B.: Major outer membrane proteins of Escherichia coli strains of human origin. J. Gen. Microbiol. 121 (1980b) 373-380.

Overbeeke, N. and Lugtenberg, B.: Recognition site for phosphorus-containing compounds and other negatively charged solutes on the PhoE protein pore of the outer membrane of Escherichia coli K-12. Eur. J. Biochem. 126 (1982) 113-118.

Overbeeke, N., Bergmans, H., van Mansfeld, F. and Lugtenberg, B.: Complete nucleotide sequence of phoE, the structural gene for the phosphate limitation inducible outer membrane pore protein of Escherichia coli K-12. J. Mol. Biol. 163 (1983) 513-532.

Pugsley, A.P. and Rosenbusch, J.P.: OmpF porin synthesis in Escherichia coli strains B and K-12 carrying heterologous $o m p B$ and/or $o m p F$ loci. FEMS Microbiol. Lett. 16 (1983) 143-147.
Tanaka, T. and Weisblum, B.: Construction of a colicin E1-R factor composite plasmid in vivo. J. Bacteriol. 121 (1975) 354-362.

Tommassen, J. and Lugtenberg, B.: Outer membrane protein e of Escherichia coli $\mathrm{K}-12$ is co-regulated with alkaline phosphatase. J. Bacteriol. 143 (1980) 151-157.

Tommassen, J. and Lugtenberg, B.: Localization of phoE, the structural gene for outer membrane protein e in Escherichia coli K-12. J. Bacteriol. 147 (1981) 118-123.

Tommassen, J., De Geus, P., Lugtenberg, B., Hackett, J. and Reeves, P.: Regulation of the pho regulon of Escherichia coli $\mathrm{K}-12$. Cloning of the regulatory genes $p h o B$ and $p h o R$ and identification of their gene products. J. Mol. Biol. 157 (1982a) 265-274.

Tommassen, J., Overduin, P., Lugtenberg, B. and Bergmans, H.: Cloning of phoE, the structural gene for the Escherichia coli phosphate limitation-inducible outer membrane pore protcin. J. Bacteriol. 149 (1982b) 668-672.

Tommassen, J., Hiemstra, P., Overduin, P. and Lugtenberg, B.: Cloning of phoM, a gene involved in regulation of the synthesis of phosphate limitation inducible proteins in Escherichia coli K-12. Mol. Gen. Genet. 195 (1984) 190-194.

Tommassen, J., Van Tol, H. and Lugtenberg, B.: The ultimate localization of an outer membrane protein of Escherichia coli $\mathrm{K}-12$ is not determined by the signal sequence. EMBO J. 2 (1983) 1275-1279.

Van Alphen, W., Van Selm, N. and Lugtenberg, B.: Pores in the outer membrane of Escherichia coli K-12. Involvement of proteins $\mathrm{b}$ and $\mathrm{e}$ in the functioning of pores for nucleotides. Mol. Gen. Genet. 159 (1978) 75-83.

Van den Hondel, C.A.M.J.J., Keegstra, W., Borrias, W.E. and Van Arkel, G.A.: Homology of plasmids in strains of unicellular cyanobacteria. Plasmid 2 (1979) 323-333.

Van Gysegem, F. and Toussaint, A.: Chromosome transfer and R-prime formation by an RP4::mini-Mu derivative in Escherichia coli, Salmonella typhimurium, Klebsiella pneumoniae and Proteus mirabilis. Plasmid 7 (1982) 30-44.

Wanner, B.L. and Latterell, P.: Mutants affected in alkaline phosphatase expression: evidence for multiple positive regulators of the phosphate regulon in Escherichia coli. Genetics 96 (1980) 353-366.

Zimmerman, W. and Rosselet, A.: The function of the outer membrane of Escherichia coli as a permeability barrier to $\beta$-lactam antibiotics. Antimicrob. Agents Chemother. 12 (1977) 368-372.

Communicated by J.-P. Lecocq 